\title{
Analisis Pariwisata Budaya dalam Pengembangan Aset Lokal Perayaan Upacara Adat Dahau di Kabupaten Kutai Barat Provinsi Kalimantan Timur
}

\author{
Analysis of Cultural Tourism in the Development of Local Assets \\ Dahau Traditional Ceremony Festival in Kutai Barat Regency East \\ Kalimantan Province
}

\author{
Sri Wahyuni ${ }^{1, a)}$ \\ ${ }^{1)}$ Sekolah Tinggi Pariwisata Ambarrukmo (STIPRAM), Yogyakarta. \\ Koresponden : ${ }^{a)}$ yiyieid@yahoo.com
}

\begin{abstract}
ABSTRAK
Penelitian bertujuan untuk mengkaji dan menganalisis kegiatan Dahau dalam rangka untuk menentukan format, lingkup, serta sasaran kegiatan yang lebih efektif, guna mendukung pembangunan dan melihat dampak ekonomi yang terjadi pada masyarakat daerah Kutai Barat Penelitian menggunakan metode penelitian kualitatif dengan bentuk strategi studi kasus terpancang. Sumber data yang digunakan yaitu informan, tempat dan peristiwa, dan dokumen. Teknik pengumpulan data menggunakan teknik observasi langsung, wawancara mendalam, dan studi dokumen. Teknik sampling menggunakan purposive sampling. Validitas data menggunakan triangulasi dan teknik analisa data menggunakan teknik analisis interaktif. Upacara Adat Dahau bagi masyarakat Kutai Barat di Kalimantan Barat mempunyai beberapa fungsi, yaitu fungsi spiritual, sosial, dan sebagai aset yang menunjang pariwisata. Upacara Adat Dahau juga bertujuan untuk meningkatkan rasa persaudaraan dan gotong royong diantara sesama warga masyarakat yang ikut terlibat dalam pelaksanaan upacara adat tersebut.
\end{abstract}

Kata Kunci : manajemen fasilitas, upacara adat Dahau, budaya lokal, kehidupan sosial ekonomi.

\section{PENDAHULUAN}

Pariwisata adalah sebuah kegiatan dimana dilakukan oleh beberapa orang atau seseorang dalam suatu perjalanan yang dapat melebihi 24 jam dari tempat tingalnya. Menurut Spillane (1987:21), dalam arti luas pariwisata adalah perjalanan dari suatu tempat ke tempat lain, bersifat sementara, dilakukan perorangan maupun kelompok, sebagai usaha mencari keseimbangan atau keserasian dan kebahagiaan dengan lingkungan hidup dalam dimensi sosial, budaya, alam dan ilmu. Ditambahkan pula bahwa pariwisata terbagi atas beberapa jenis, yaitu : pariwisata untuk menikmati perjalanan (pleasure tourism), pariwisata untuk berekreasi (recreation tourism), pariwisata untuk kebudayaan (culture tourism), pariwisata untuk olahraga (sports tourism), pariwisata untuk urusan usaha dagang (business tourism), pariwisata untuk berkonvensi (convention tourism).

Guyer Freuler dalam Oka A. Yoeti (1983) merumuskan pengertian pariwisata dengan memberikan batasan yakni "Pariwisata dalam artian modern adalah merupakan fenomena dari zaman sekarang yang didasarkan atas kebutuhan akan kesehatan dan pergantian hawa, penilaian yang sadar dan menumbuhkan cinta terhadap keindahan alam dan pada khususnya disebabkan oleh bertambahnya pergaulan berbagai bangsa dan kelas masyarakat manusia sebagai hasil dari pada perkembangan perniagaan, perdagangan serta penyempurnaan dari pada alat-alat pengangkutan". 
Menurut Herman Von Schulalard (1910) dalam Yoeti (1983), telah memberikan batasan pariwisata sebagai berikut :

"Tourism is the sum of operations mainly of an economic nature, which directly related to the entry, stay ang movement of foreigner inside certain country, city or region".

Menurut pendapatnya, yang dimaksudkan dengan kepariwisataan adalah sejumlah kegiatan, terutama yang ada kaitannya dengan kegiatan perekonomian yang secara langsung berhubungan dengan masuknya, adanya pendiaman dan bergeraknya orang-orang asing keluar masuk suatu kota, daerah atau negara (Yoeti, 1983: 99).

Menyoroti pariwisata dari aspek ekonomi, dimana pariwisata adalah istilah bagi semua, lebih-lebih bagi aspek ekonomi, proses yang ditimbulkan oleh lalu lintas orang asing yang datang dan pergi dari suatu tempat, daerah atau negara dan segala sesuatunya yang ada sangkut pautnya dengan proses tersebut (Pendit, 1999: 38). Menurut Spillane (1994: 28-30) terdapat empat pendekatan didalam pariwisata yang muncul secara kronologis yakni :

- Pendekatan Advocasy: Pendekatan ini mendukung pariwisata dan menekankan keuntungan ekonomis dari pariwisata. Potensi pariwisata bisa dipakai untuk mendukung macam-macam kegiatan ekonomis, menciptakan lapangan kerja baru, memperoleh devisa asing yang dibutuhkan bagi pembangunan dan masih banyak lagi.

- Pendekatan Cautionary : Pendekatan ini menekankan bahwa pariwisata banyak mengakibatkan banyak kerugian (disbenefits) dalam berbagai aspek sosial-ekonomi: seperti menimbulkan lapangan kerja musiman dan kasar (rendahan), mengakibatkan kebocoran devisa asing, menyebabkan komersialisasi budaya, serta menyebabkan berbagai macam konflik.

- Pendekatan Adaptancy : Pendekatan ini menyebutkan agar pengaruh negatif pariwisata dapat dikontrol dengan mencari bentuk lain perkembangan pariwisata dari yang selama ini sudah dikenal secara umum, atau dengan menyesuaikan pariwisata dengan Negara atau daerah tujuan wisata. Cara berpikir baru ini berdasarkan pandangan bahwa alam dan budaya dapat digabungkan dalam satu konteks.

- Pendekatan Developmental : Pendekatan Developmental atau sering disebut pendekatan Alternative ini menganggap bahwa pariwisata dapat disesuaikan dengan keadaan masyarakat tuan rumah dan peka akan selera masyarakat tuan rumah tersebut. Dapat dipercaya bahwa perkembangan tersebut sebetulnya mempengaruhi pilihan wisatawan terhadap daerah tujuan wisatanya dan demikian juga kehidupan mereka didaerah tujuan wisata atau bentuk alternative pariwisata ini mempengaruhi jurang pemisah antara hak dan kewajiban dari tamu, tuan rumah dan perantaranya.

Sejak tahun 1970-an, pembangunan di Indonesia lebih mengarah pada modernisasi yang berdampak pada terjadinya transformasi sosial dari masyarakat tradisional menuju modern. Semuanya itu terjadi melalui pertumbuhan ekonomi dan industrialisasi. Sayangnya, setelah beberapa dekade, pola pembangunan semacam itu menuai kritik karena tidak kunjung memberikan dampak signifikan pada peningkatan kesejahteraan masyarakat.

Hingga kemudian muncul kritik atas pembangunan, yaitu: (1) Pembangunan yang menekankan pada industrialisasi telah menghancurkan sistem, norma-norma tradisional kolektif dan modal sosial (Fukuyama, 1999); (2) Tidak hanya kehidupan mulai bersifat individualis tetapi pembangunan telah memunculkan aleniasi dan kekerasan, baik verbal maupun simbolik, sehingga kehidupan terasa hampa tanpa makna (Hardiman, 2007: 42-63); (3) Pembangunan telah mematikan kemampuan masyarakat perdesaan (lokal) untuk menolong diri mereka sendiri (Erler 1989); dan (4) Pembangunan membuat masyarakat sangat tergantung pada bantuan dari luar. Situasi ini tidak hanya mempersulit mereka untuk keluar dari pusaran kemiskinan dan keterbelakangan tetapi juga telah menyebabkan ketidakberdayaan (Friedman, 1992: 14-36).

Kritik di atas memunculkan pendekatan pembangunan yang baru, yaitu pengembangan aset lokal (local asset development). Hal ini senada dengan adanya desentralisasi yang mana kekuatan pembangunan ada pada level lokal, baik stakholder maupun masyarakat setempat. 
Oleh karenanya, penting magi suatu masyarakat untuk memetakan potensi-potensi yang mereka miliki, khususnya pada komunitas.

Selain itu Obyek Wisata harus dikelola dengan baik disepanjang Siklus Hidupnya sesuai dengan prinsip Manajemen Aset Fasilitas. Obyek Wisata harus dikelola sesuai dengan Permintaan Wisata yang ada, secara ekonomis, efisien dan efektif, serta harus selaras dengan prinisp berkelanjutan (Soemitro \& Suprayitno, 2018).

Salah satu potensi lokal yang sangat menarik ialah perayaan Dahau di Kabupaten Kutai Barat, Provinsi Kalimantan Timur. Perayaan Dahau merupakan kegiatan perayaan ulang tahun yang melibatkan pelbagai etnis lokal. Kegiatan ini ke depannya dapat dijadikan magnet dalam menarik wisatawan, sehingga roda perekonomian akan berputar kencang di kabupaten ini.

\section{STUDI PUSTAKA}

Pemberdayaan masyarakat adalah upaya meningkatkan kemampuan dan potensi yang dimiliki masyarakat, sehingga masyarakat dapat mewujudkan jati diri, harkat dan martabatnya secara maksimal untuk bertahan dan mengembangkan diri secara mandiri baik dibidang ekonomi, sosial, agama dan budaya (Widjaja, 2003:169). Maka dari itu perayaan Dahau, sebagai sebuah aset lokal kebudayaan dan pariwisata yang harus dilestarikan sudah seharusnya mempunyai payung hukum yang dapat menjaga eksistensi dari Perayaan Dahau tersebut. Dari berbagai pendapat dari masyarakat tersebut maka memang penyelenggaraan Dahau di Kabupaten Kutai Barat sangat erat kaitannya dengan sektor pariwisata. Usaha mengangkat sektor pariwisata suatu daerah mempunyai arti usaha untuk mendatangkan wisatawan ke daerah yang bersangkutan. Maka nantinya dengan keberlanjutan penyelenggaraan Dahau Kutai Barat, selain untuk memperkenalkan potensi daerah juga diharapkan mampu meningkatkan kunjungan wisatawan. Adapun ketika daya tarik wisata ada maka akan ada beberapa sektor lain yang ikut terangkat, diantaranya transportasi, akomodasi, atraksi, dan kuliner. Diharapkan masyarakat dapat memanfaatkan sektor-sektor ini untuk menunjang perekonomian.

Hal diatas sesuai dengan UU RI No. 10 tahun 2009 tentang kepariwisataan, dimana menurut Undang-Undang RI nomor 10 tahun 2009 tentang Kepariwisataan Bab 1 pasal 1 dinyatakan bahwa wisata adalah kegiatan perjalanan yang dilakukan oleh seseorang atau kelompok orang dengan mengunjungi tempat tertentu untuk tujuan rekreasi, pengembangan pribadi atau mempelajari keunikan daya tarik wisata yang dikunjungi dalam jangka waktu sementara. Sedangkan Bab II pasal 2, menyatakan Kepariwisataan diselenggarakan berdasarkan asas: manfaat, kekeluargaan, adil dan merata, keseimbangan, kemandirian, kelestarian, partisipatif, berkelanjutan, demokratis, kesetaraan dan kesatuan.

Hal tersebut didukung secara teoritis, sebagaimana menurut Murphy (1985) dalam Pitana dan Gayatri (2005 : 45), pariwisata adalah keseluruhan dari elemen-elemen terkait (wisatawan, daerah tujuan wisata, perjalanan, industri dan lain-lain) yang merupakan akibat dari perjalanan wisata ke daerah tujuan wisata, sepanjang perjalanan tersebut tidak permanen.

Selanjutnya, dalam sudut pandang ilmu sosiologi, seperti diungkapkan Sunyoto Usman (1998) bahwa kegiatan pariwisata sekurang-kurangnya mencakup tiga dimensi interaksi, yaitu kultural, politik, dan bisnis. Karena pariwisata menyangkut manusia dan masyarakat, secara sosiologis pariwisata mempunyai ruang lingkup sebagai berikut :

- Pariwista telah menjadi aktivitas ekonomi dominan dewasa ini

- Pariwisata sangat terkait dengan masalah sosial, ekonomi, politik, keamanan, ketertiban, keramah-tamahan, kebudayaan, dan berbagai institusi sosial yang mengaturnya

- Pariwisata bersifat sangat dinamis sehingga setiap saat memerlukan analisis yang tajam dalam rangka memberikan manfaat bagi masyarakat lokal khususnya

- Pariwisata tidak bersifat eksklusif atau menyangkut suku bangsa tertentu atau kelas tertentu

- Adanya proses akulturasi, dominasi, sosialisasi, adopsi, adaptasi, dalam kaitan hubungan antar budaya dan masyarakat 
- Pengaruh pariwisata sudah sangat meluas sehingga telah menjadi prime mover dalam perubahan sosial

- Berkembangnya berbagai lembaga yang terkait dengan pariwisata

Pengembangan sektor pariwisata harus sinergi dengan kebijakan untuk memberdayakan masyarakat lokal. Misalnya kesenian dan kebudayaan masyarakat lokal bisa diangkat untuk dijadikan hiburan bagi wisatawan pada saat pelaksanaan Dahau Kutai Barat. Seni dan budaya lokal bisa didesain sedemikian rupa untuk dijadikan alat peningkatan ekonomi masyarakat. Wisatawan yang mendatangi suatu destinasi wisata tentunya tidak hanya ingin keindahan tempat saja, namun juga mencari alternatif wisata lain seperti keaslian seni dan tradisi masyarakat lokal. Dan pastinya sebagai masyarakat asli daerah tersebut memiliki berbagai macam bentuk seni budaya lokal yang bisa mereka suguhkan kepada wisatawan. Celah inilah yang bisa dimanfaatkan oleh warga lokal untuk ikut memanfaatkan pariwisata di Kutai Barat. Upacara adalah sistem aktivitas atau rangkaian atau tindakan yang ditata oleh adat atau hukum yang berlaku dalam masyarakat yang berhubungan dengan berbagai macam peristiwa tetap yang biasanya terjadi dalam masyarakat yang bersangkutan (Koentjaraningrat, 1980:140). Jenis upacara dalam kehidupan masyarakat antara lain: upacara kelahiran, upacara perkawinan, upacara penguburan dan upacara pengukuhan kepala suku. Upacara pada umumnya memiliki nilai sacral oleh masyarakat pendukung kebudayaan tersebut. Upacara adat adalah suatu upacara yang secara turun-temurun dilakukan oleh pendukungnya di suatu daerah. Dengan demikian setiap daerah memiliki upacara adat sendiri-sendiri seperti upacara adat perkawinan, kelahiran dan kematian. Upacara adat yang dilakukan memiliki berbagai unsur: Menurut Koentjaraningrat (1980) ada beberapa unsur yang terkait dalam pelaksanaan upacara adat diantaranya adalah :

- Tempat berlangsungnya upacara Tempat yang di gunakan untuk melangsungkan suatu upacara biasanya adalah tempat keramat atau bersifat sacral/suci, tidak setiap orang dapat mengunjungi tempat tersebut. Tempat tersebut hanya dikunjungi oleh orang-rang yang berkepentingan, dalam hal ini adalah orang yang terlibat dalam dalam pelaksanaan upacara seperti pemimpin upacara.

- Saat berlangsungnya upacara/waktu pelaksanaan Waktu pelaksanaan upacara adalah saat-saat tertentu yang dirasakan tepat untuk melangsungkan upacara

- Benda-benda atau alat upacara Benda-benda atau alat dalam pelaksanaan upacara adalah sesuatu yang harus ada semacam sesaji yang berfungsi sebagai alat dalam sebuah upacara adat.

- Orang-orang yang terlibat didalamnya Orang-orang yang telibat dalam upacara adat adalah mereka yang bertindak sebagai pemimpin jalanya upacara dan beberapa orang yang paham dalam ritual upacara adat (Koentjaraningrat 1980:241). Dalam masyarakat dikenal berbagai jenis upacara adat salah satunya upacara adat perkawinan. Menurut Thomas Wiyasa yang dimaksud dengan upacara adat perkawinan merupakan serangkaian kegiatan tradisional turun temurun yang mempunyai maksud dan tujuan agar perkawinan akan selamat sejahtera serta mendatangkan kebahagian di kemudian hari (Thomas Wiyasa, 2002:1).

\section{METODOLOGI}

Penelitian dilakukan di Kabupaten Kutai Barat Kalimantan Timur. Kabupaten Kutai Barat memiliki berbagai macam kebudayaan yang penting untuk diketahui, dijaga, dan dilestarikan. Salah satunya adalah upacara adat Dahau, pergeseran nilai yang terdapat didalamnya berdampak terhadap kehidupan sosial ekonomi masyarakat sekitar. Menurut Sutopo (2006: 135) sebelum merancang pelaksanaan penelitian, perlu dipahami bahwa terdapat dua jenis penelitian, yang dibedakan dari tujuan akhirnya. Data kualitatif yang dikumpulkan terutama berupa kata-kata, kalimat atau gambar yang memiliki arti lebih 
bermakna dan mampu memacu pemahaman yang lebih nyata daripada sekedar sajian angka atau frekuensi (Sutopo, 2006: 40). Atas dasar bentuk penelitain tersebut, maka penelitian dilakukan dengan tiga tahap, yaitu tahap orientasi, tahap eksplorasi, dan tahap member check. Adapun strategi yang digunakan adalah studi kasus terpancang tunggal. Dikatakan studi kasus tunggal karena memfokuskan pada kasus yaitu pergerakan ekonomi masyarakat dalam Upacara Adat Dahau. Selain alasan tersebut, dikatakan sebagai studi kasus terpancang karena peneliti sudah membatasi pada rumusan masalah sebelum ke lapangan. Studi deskriptif merupakan penelitian yang dimaksudkan untuk mengumpulkan informasi mengenai status suatu gejala yang ada, yaitu keadaan gejala menurut apa adanya pada saat penelitian dilakukan. Dalam kegiatan studi deskriptif akan digali berbagai data yang berhubungan dengan kehidupan sosial ekonomi masyarakat di Kutai Barat Kalimantan Timur. Adapun sumber data yang digunakan dalam penelitian adalah: (1) informan. Yang termasuk informan dalam penelitian adalah tokoh masyarakat Dayak dan pelaku upacara Adat Dahau seperti ketua adat, panitia pelaksana Upacara Adat Dahau, serta masyarakat sekitar Kutai Barat; (2) tempat pelaksanaan Upacara Adat Dahau di Kutai Barat Kalimantan Timur; dan (3) dokumen berupa dokumen surat-surat, foto maupun rekaman. Teknik pengumpulan data yang digunakan adalah: (1) observasi langsung yang bersifat partisipasi pasif maupun aktif dimana peneliti dapat mengamati obyek penelitian; (2) wawancara mendalam (indepth interview) yang dilakukan lebih menyerupai suatu bentuk dialog antara peneliti dan informan dilakukan dalam suasana santai; dan (3) mengkaji dokumen dan arsip (content analysis) tentang sikap masyarakat terhadap pergerakan perekonomian masyarakat dalam Upacara Adat Dahau di Kutai Barat Kalimantan Timur.

\section{HASIL DAN DISKUSI}

Merujuk pada pengumpulan data yang telah dilakukan terkait dengan penelitian ini, menghasilkan sebuah perspektif yang positif yang diberikan oleh masyarakat Kutai Barat terkait perayaan Dahau ini. Mayoritas masyarakat sangat mendukung dengan diselenggarakannya festival tahunan Dahau ini, tentunya dengan banyak syarat agar event ini dapat memberikan manfaat yang lebih luas bagi masyarakat secara keseluruhan. Keinginan dari masyarakat demi terwujudnya festival Dahau yang lebih baik antara lain :

1. Pemerintah melakukan penataan UKM dan stand pameran dengan memberikan tempat tersendiri, semisal penjual makanan bisa dijajarkan di sepanjang jalan di samping Lamin sehingga para pengunjung mudah dan nyaman mencari makanan. Diadakan festival kuliner. Menggelar perlombaan tradisional yang menarik yang diharapkan menarik masyarakat ikut serta. Serta lebih meningkatkan kerajinan tangan khususnya kerajiana tangan Kutai barat. Diharapkan melalui acara Dahau yang memakai acara kesenian daerah itu sendiri akan lebih bisa menjadikan budaya kesenian daerah lebih maju lagi dan tidak perlu memakai artis dari luar daerah. Agar masyarakat mengetahui acara apa saja yang ditampilkan akan menarik jika dibuatkan jadwal seperti baliho yang terpampang di depan/di area umum. dibuatkan media center informasi. Disiapkan lahan parkir agar parkir tidak dilakukan di badan jalan.

2. Kegiatan Dahau yang selama ini diadakan sudah cukup bagus tapi masih kurang dalam promosi keluar wilayah Kutai Barat. Akan sangat mendukung jika kegiatan Dahau dibuat website/blog yang membahas kegiatan Dahau (sebagai bagian promosi) pariwisata di Kutai Barat. Menjadikan festival Dahau sebagai media pariwisata yang dapat menarik wisatawan terhadap perayaan Dahau dengan lebih sering diiklankan di bandara-bandara ataupun di kegiatan-kegiatan nasional, juga promosi yang lebih progresif keluar kabupaten sehingga menjadi paket wisata yang prospektif, serta didukung dengan memperbaiki infrastuktur yang sudah mulai rusak di tempat-tempat wisata. Iklan di radio, surat kabar, dan lain sebagainya mengenai kegiatan Festival 
Dahau untuk menarik masyarakat agar lebih tertarik untuk datang menyaksikan kegiatan tersebut. Kesenian daerah/ciri khas Kutai Barat perlu dikembangkan lagi misalnya : tari-tarian setiap etnis yang ada.

3. Festival Dahau melibatkan anak didik kita dengan masuk di setiap sekolah, agar anak sekolah bisa mengerti tentang sejarah Kutai Barat. Dan permintaan yang besar dari masyarakat agar mengundang seluruh lapisan masyarakat untuk datang menyaksikan dan merasakan arti makna syukuran Kutai barat, untuk makan bersama-sama antar pemerintah seperti yang dapat dilihat di Tenggarong, dengan menyelenggarakan acara tersebut diselenggarakan di puncak acara.

4. Masyarakat meminta agar barang-barang yang dijual jangan terlalu mahal. Dan perlu diperjelas manfaat dari perayaan dahau untuk ekonomi masyarakat, generasi muda dan pengembangan sektor pariwisata. Untuk perayaan dahau perlu mengundang masyarakat dari kabupaten/kota lain untuk mengenalkan budaya dan adat istiadat yang ada di kab. kutai barat. bisa melalui media elektronik ataupun tulisan.

5. Diadakan makan bersama antar pemerintah dan masyarakat, karena untuk mensyukuri akan berkat yang diberikan oleh Tuhan kepada masyarakat Kutai Barat. Hal ini kiranya bisa menjadi ajang sosialisasi untuk menjangkau masyarakat lapisan bawah. semaksimal mungkin untuk berusaha merangkul masyarakat kecil, menengah dan atas, terutama dalam memberikan tempat agar bisa menampilkan ciri khas seperti pakaian adat dari setiap suku yang ada di wilayah Kabupaten Kutai Barat.

6. Untuk kegiatan Dahau, karena kegiatan tersebut adalah bercorak khas daerah dan budaya khas daerah (Kutai Barat), sebaiknya dimeriahkan sesuai dengan tradisi (6 etnis yang ada di Kutai Barat, yaitu: Dayak, Tunjung, Benuaq, Bahau, Kenyah, Bentian). Selain itu, perlu pembenahan obyek wisata yang ada agar menarik minat wisatawan berkunjung ke obyek wisata itu dan menerima manfaat dari kunjungan mereka, pengadaan sarana pariwisata seperti bus pariwisata untuk antara jemput pengunjung ke obyek wisata dengan tarif terjangkau oleh masyarakat, petugas pemandu wisata yang menguasai sejarah/mitos setiap obyek wisata, dan memerlukan petugas penjaga dan pemelihara obyek wisata agar selalu terkesan bersih dan asri sesuai motto Kutai Barat: Beradat.

7. Perlunya jaminan keamanan dan juga kebersihan bagi peserta maupun pengunjung festival Dahau.

Dari masukan yang diberikan oleh masyarakat Kutai Barat melalui survei yang dilakukan terlihat bahwa masyarakat sudah menyadari bahwa perayaan Festival Dahau ini tidak hanya diartikan sebagai sebuah perayaan untuk masyarakat Kutai Barat semata, tetapi perayaan ini mempunyai potensi wisata dengan mendatangkan pengunjung dari luar daerah, bahkan dari luar negeri. Ini mempunyai arti bahwa masyarakat Kutai Barat sudah siap dengan kehadiran orang dari luar daerah mereka, akan menyambut dengan tangan terbuka kehadiran mereka.

Hal yang ditekankan oleh masyarakat terkait pola interaksi antara masyarakat lokal dengan wisatwan dari luar adalah, dikarenakan adanya potensi perbedaan budaya yang dibawa oleh para pendatang, di sektor pariwisata ini harus ada penjembatan antara masyarakat lokal dengan para wisatawan melalui para pemandu wisata yang dapat menjelaskan bagaimana adat istiadat masyarakat setempat sehingga perbedaan tersebut dapat saling dipahami.

Dalam kerangka pelaksanaan kegiatan pariwisata seperti Dahau Kutai Barat, pemerintah harus bisa mendorong masyarakat lokal untuk memanfaatkan peluang dalam dunia pariwisata. Ketika alasan sumber daya manusia belum memiliki kapasitas untuk memanfaatkan sektor pariwisata, maka kewajiban pemerintah untuk membangun kualitas sumber daya manusia setempat. Karena bagaimanapun juga untuk pembangunan ekonomi melalui sektor pariwisata 
harus dibarengi dengan pembangunan sumber daya manusia juga, terutama bagi warga lokal. Ini terkait dengan UU No. 10 Tahun 2009 yang juga menyebutkan bahwa pariwisata adalah berbagai macam kegiatan wisata dan didukung berbagai fasilitas serta layanan yang disediakan oleh masyarakat, pengusaha, pemerintah, dan pemerintah daerah.

Aktivitas wisata pada hakikatnya merupakan salah satu kebutuhan tersier untuk menghilangkan kepenatan yang diakibatkan oleh aktivitas. Umumnya orang berlibur ke tempa-tempat yang menawarkan kenyaman, keamanan, dan tentunya hiburan. Mencari tempat berlibur yang kita inginkan dan yang sesuai dengan kebutuhan kita tidaklah sulit di jaman modern ini. Banyak promosi yang dilakukan negara-negara, tempat wisata, travel, dan lainlain untuk menarik minat wisatawan. Berbagai promosi yang dilakukan seperti iklan, diskon, pameran, website, event dan lain-lain. Kunci utama kedatangan wisatawan/pengunjung atau suksesnya program pariwisata sangat bergantung pada aktivitas dan strategi promosi yang dilakukan.

Pengelolaan potensi pariwisata adalah upaya merencanakan, melaksanakan, memantau, dan mengevaluasi penyelenggaraan kegiatan pariwisata, pendayagunaan sumber daya ekonomi lokal, dan pengendalian terhadap dampak yang ditimbulkan dari kegiatan kepariwisataan tersebut. Pola pengelolaan potensi pariwisata adalah kerangka dasar dalam merencanakan, melaksanakan, memantau, dan mengevaluasi penyelenggaraan kegiatan kepariwisataan, pendayagunaan sumber daya ekonomi lokal, dan pengendalian terhadap dampak dari kegiatan pariwisata.

Berdasarkan kuesioner yang ada, terdapat 13 kuesioner dari 7 kecamatan yang mewakili

16 kecamatan yang ada dan mengumpulkan kuesioner, namun kuesioner yang mewakili kecamatan tersebut hanya 13 yang diolah karena terdapat satu kuesioner yang tidak mengisi secara lengkap. Untuk melihat karakteristik masing-masing kecamatan dari aspek sosial budaya, dalam kuesioner ditanyakan tentang kekhasan sosial budaya yang ada di masingmasing kecamatan.

Dari hasil pengolahan kuesioner, ada 5 kecamatan yang memiliki kesenian tradisional dan 2 kecamatan tidak memilikinya. Hal ini menunjukkan bahwa Kutai Barat memiliki potensi budaya dan kesenian yang cukup besar untuk dilestarikan dan dikembangkan. Kesenian yang ada di kecamatan tersebut juga ditampilkan pada acara-acara tertentu. Terdapat 4 kecamatan yang selalu menampilkan kesenian khas kecamatan yaitu kecamatan Sekolaq Darat, Long Iram, Bongan, dan Muara Pahu sementara kecamatan Linggang Bigung, Nyuatan, dan Siluq Ngurai sering menampilkan kesenian khas mereka. Kesenian yang ada di kecamatan tersebut sudah dikenal luas oleh masyarakat lain di luar kecamatan.

Potensi lain yang ada di kecamatan adalah adanya budaya khas di masing-masing kecamatan, dan budaya tersebut juga sudah dikenal luas oleh masyarakat di luar kecamatan. Selain itu, kecamatan juga memiliki kerajinan khas yang potensial untuk dibina dan dikembangkan termasuk dipasarkan sebagai kekayaan khas Kutai Barat.

Berdasarkan 13 responden dari 7 kecamatan, 6 responden menyatakan "selalu" menyaksikan acara Dahau, dan 6 responden lain menyatakan "sering" menyaksikan dan satu responden menyatakan "jarang". Tidak ada responden yang menyatakan "tidak pernah" menyaksikan Dahau. 


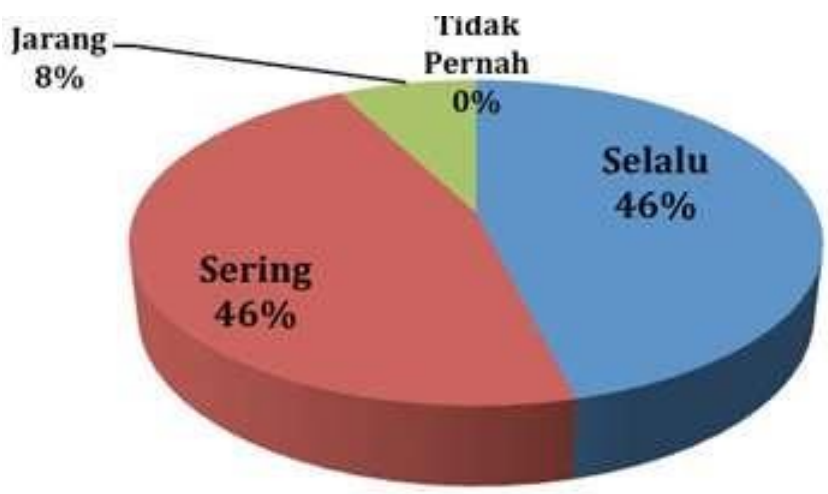

Gambar.1 Grafik Data Primer

Pada saat acara Dahau, beberapa kecamatan selalu menampilkan kesenian khas kecamatan misalnya kesenian dari kecamatan Muara Pahu, Siluq Ngurai, dan Sekolaq Darat. Demikian juga dengan atraksi budaya, meski tidak selalu tampil dalam acara Dahau namun beberapa kecamatan sering menampilkan atraksi tersebut dalam kegiatan Dahau.

Acara puncak Dahau berisi upacara adat, kesenian, serta hiburan bagi masyarakat. Kegiatan ini mampu menyedot ketertarikan masyarakat untuk menyaksikan seluruh rangkaian acara. Kondisi ini juga mendorong efek multiplier berupa berkembangnya aktivitas ekonomi masyarakat selama kegiatan berlangsung dalam bentuk perdagangan berbagai jenis barang. Selama kegiatan berlangsung, sebanyak $21 \%$ responden menyatakan selalu belanja, $31 \%$ menyatakan sering belanja, dan $41 \%$ menyatakan jarang belanja. Hanya $1 \%$ responden menyatakan tidak pernah berbelanja selama kegiatan Dahau berlangsung. Hal ini mengindikasikan bahwa kegiatan Dahau mampu mendorong munculnya aktivitas ekonomi masyarakat, bukan hanya hiburan semata. Dengan pengelolaan yang lebih baik serta format kegiatan yang berbeda, Dahau akan memberikan dampak yang lebih besar bagi pengembangan ekonomi dan dinamika masyarakat. Sebagian besar barang yang diperjualbelikan selama Dahau adalah makanan dan minuman. Hal ini terlihat dari $41 \%$ responden yang menyatakan bahwa mereka berbelanja makanan dan minuman. Sementara itu sebanyak $26 \%$ berbelanja barang kerajinan dan $11 \%$ berbelanja untuk mainan anak-anak. Kondisi ini menggambarkan bahwa acara Dahau melibatkan seluruh lapisan masyarakat mulai anak-anak hingga orang tua.

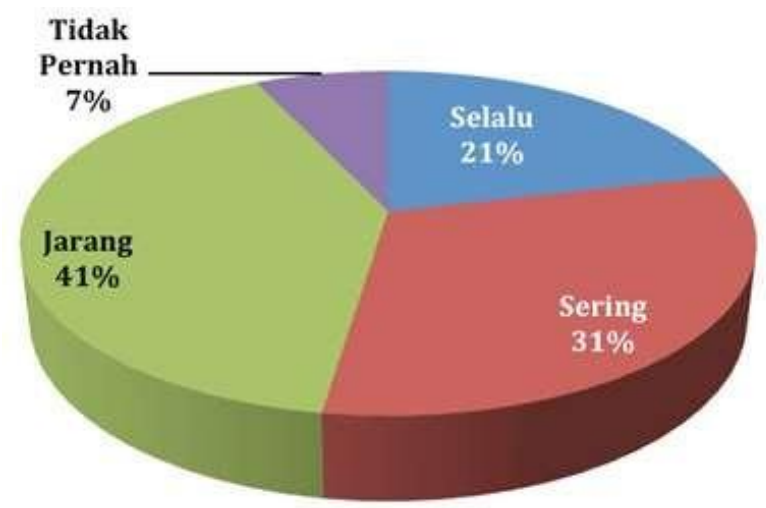

Gambar.2 Grafik Data Primer Frekuensi Belanja Selama Kegiatan Dahau 


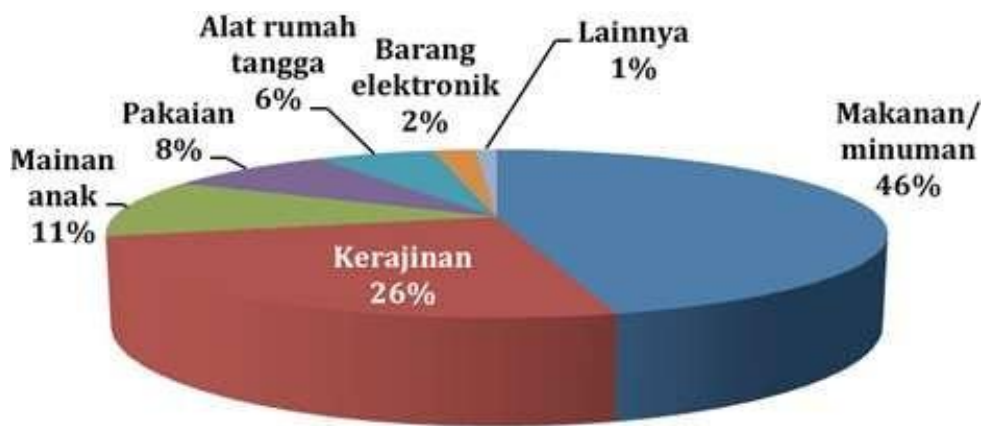

Gambar.3 Grafik Data Primer Jenis Barang yang Dibeli Selama Acara Dahau

Menurut responden, kegiatan Dahau mampu memberikan dampak dalam menggerakkan ekonomi masyarakat. Hal ini terlihat dari jawaban sekitar $80 \%$ responden yang menyatakan bahwa kegiatan Dahau akan membawa dampak besar dan cukup besar dalam menggerakkan ekonomi masyarakat. Di samping itu, sekitar $77 \%$ responden juga meyakini bahwa Dahau akan menarik wisatawan dari luar Kutai Barat dan lebih dari 90\% menyatakan bahwa Dahau mampu menggerakkan sector pariwisata di Kutai Barat. Dengan demikian, pengelolaan Dahau yang lebih baik akan mendorong pembangunan Kutai Barat yang lebih baik khususnya dalam bidang sosial budaya kemasyarakatan, yang pada akhirnya berdampak pada bidang ekonomi.

Tabel. 1 Persepsi Responden Terhadap Dampak Kegiatan Dahau $(\%)$

\begin{tabular}{lcccc}
\hline $\begin{array}{l}\text { Dampak Dahau terhadap hal-hal } \\
\text { di bawah ini }\end{array}$ & Besar & $\begin{array}{c}\text { Cukup } \\
\text { Besar }\end{array}$ & Kecil & $\begin{array}{c}\text { Tidak } \\
\text { Ada }\end{array}$ \\
\hline $\begin{array}{l}\text { Menggerakan ekonomi masyarakat } \\
\text { Meningkatkan pendapatan daerah }\end{array}$ & 37.41 & 42.22 & 15.19 & 5.19 \\
$\begin{array}{l}\text { Menarik minat wisatawan dari luar } \\
\text { Kutai Barat }\end{array}$ & 37.78 & 47.41 & 11.85 & 3.33 \\
$\begin{array}{l}\text { Memperkuat persatuan masyarakat } \\
\text { Kutai Barat }\end{array}$ & 50.00 & 41.48 & 7.41 & 0.74 \\
$\begin{array}{l}\text { Melestarikan budaya/adat masyarakat } \\
\text { Kutai Barat }\end{array}$ & 51.85 & 44.44 & 3.33 & 0.37 \\
$\begin{array}{l}\text { Mengembangkan sektor pariwisata di } \\
\text { Kutai Barat }\end{array}$ & 45.56 & 44.44 & 8.15 & 1.48 \\
\begin{tabular}{l} 
Media hiburan masyarakat \\
\hline
\end{tabular} & 53.70 & 43.33 & 2.59 & 0.37 \\
\hline
\end{tabular}

Sumber: Data Primer

Pengelolaan Dahau yang lebih baik di masa mendatang antara lain dapat terukur dari format acara yang lebih variatif, peningkatan peran serta masyarakat, serta dampaknya bagi pembangunan daerah. Dalam format acara Dahau misalnya, sebagian besar responden menyatakan perlunya dalam rangkaian kegiatan Dahau dilakukan kegiatan-kegiatan berupa pameran atau expo, hiburan rakyat, lomba-lomba antar kampong atau wilayah, festival kuliner, festival budaya, serta karnaval yang semuanya diharapkan mampu melibatkan masyarakat secara aktif. Mayoritas responden menyatakan pentingnya kegiatan Dahau diisi dengan acara-acara tersebut. Hal ini dapat berdampak secara psikologis pada sense of belonging masyarakat dalam kegiatan Dahau itu sendiri. 
(e)ISSN 2615-1847 (p)ISSN 2615-1839

Jurnal Manajemen Aset Infrastruktur \& Fasilitas - Vol. 3, No. 1, Maret 2019

Tabel.2 Persepsi Responden Terhadap Perluanya Beberapa Kegiatan dalam Rangka Dahau

\begin{tabular}{lccc}
\hline $\begin{array}{l}\text { Jenis kegiatan DAHAU dalam } \\
\text { rangka HUT Kutai Barat }\end{array}$ & Perlu & $\begin{array}{r}\text { Kurang } \\
\text { Perlu }\end{array}$ & $\begin{array}{c}\text { Tidak } \\
\text { perlu }\end{array}$ \\
\hline Pameran/expo & 90.71 & 8.18 & 1.12 \\
Hiburan rakyat (musik, kesenian) & 94.80 & 4.83 & 0.74 \\
Lomba-lomba antar kampung & 88.85 & 6.32 & 4.46 \\
Festival kuliner & 89.96 & 8.18 & 1.86 \\
Festival budaya & 95.54 & 4.09 & 0.74 \\
Karnaval & 82.90 & 12.27 & 4.46 \\
\hline
\end{tabular}

Sumber: Data Primer

Kemeriahan dan kesakralan Dahau memang barangkali diharapkan oleh semua lapisan masyarakat namun masyarakat tetap mengharapkan Dahau dipusatkan di pusat pemerintahan kabupaten. Hal ini terlihat dari pendapat 53\% responden yang menyatakan bahwa kegiatan Dahau cukup diselenggarakan di tingkat kabupaten. Meski demikian, pada dasarnya format kegiatan dapat disempurnakan dalam rangka mengembangkan gaung kegiatan Dahau ke seluruh wilayah kecamatan.

Dahau merupakan kegiatan yang dilaksanakan oleh seluruh elemen di Kabupaten Kutai Barat dalam rangka memperingati hari jadi daerah tersebut. Adapun dalam memandang perayaan Dahau maka kegiatan tersebut dimaknai sebagai bentuk ungkapan syukur dari pemerintah daerah dan juga seluruh kalangan masyarakat dari beragam etnis yang eksis dalam susunan masyarakat Kutai Barat. Disamping itu, perayaan Dahau yang menampilkan seni dan budaya khas Kutai Barat harapannya dapat menjadi sarana pelestarian kesenian dan kebudayaan daerah yang begitu multikultural. Pemerintah Daerah dan masyarakat Kutai Barat agar dalam penyelenggaraannya diharapkan tetap pada koridor-koridor budaya, dan sosial, serta dapat dikembangkan sesuai kebutuhan dan perkembangan zaman, tanpa menghilangkan nilai-nilai asli/lokalnya. Diharapkan Pemda dan masyarakat setempat dapat menjadikan perayaan Dahau sebagai sarana promosi daerah kepada pihak-pihak lain agar dapat meningkatkan derajat kesejahteraan di Kutai Barat.

\section{KESIMPULAN}

Dahau merupakan kegiatan yang dilaksanakan oleh seluruh elemen di Kabupaten Kutai Barat dalam rangka memperingati hari jadi daerah tersebut. Adapun dalam memandang perayaan Dahau maka kegiatan tersebut dimaknai sebagai bentuk ungkapan syukur dari pemerintah daerah dan juga seluruh kalangan masyarakat dari beragam etnis yang eksis dalam susunan masyarakat Kutai Barat. Disamping itu, perayaan Dahau yang menampilkan seni dan budaya khas Kutai Barat harapannya dapat menjadi sarana pelestarian kesenian dan kebudayaan daerah yang begitu multikultural. Pemerintah Daerah dan masyarakat Kutai Barat agar dalam penyelenggaraannya diharapkan tetap pada koridor-koridor budaya, dan sosial, serta dapat dikembangkan sesuai kebutuhan dan perkembangan zaman, tanpa menghilangkan nilai-nilai asli/lokalnya. Diharapkan Pemda dan masyarakat setempat dapat menjadikan perayaan Dahau sebagai sarana promosi daerah kepada pihak-pihak lain agar dapat meningkatkan derajat kesejahteraan di Kutai Barat.

\section{DAFTAR PUSTAKA}

Abdullah, Irwan \& Iqbal, Ibnu (2008). Agama dan Kearifan Lokal dalam Tantangan Global. Pustaka Pelajar. Yogyakarta.

Adlin, Alfahri (2007). Spiritualitas dan Realitas Kebudayaan Kontemporer. Jalasutra. 
Yogyakarta.

Badan Pusat Statistik Kabupaten Kutai Barat (2015). Kutai Barat Dalam Angka 2015.

Badan Pusat Statistik Kabupaten Kutai Barat. Kutai Barat.

Badan Pusat Statistik Kabupaten Kutai Barat (2015). Statistik Daerah Kabupaten Kutai Barat 2015. Badan Pusat Statistik Kabupaten Kutai Barat. Kutai Barat.

Bakker, S.J. J.W.M. (2005). Filsafat Kebudayaan, Sebuah Pengantar. Penerbit Kanisius. Yogyakarta.

Barker, Chris (2004). Cultural Studies Teori dan Praktik. Terjemahan Nurhadi. Kreasi Wacana. Yogyakarta.

Bevans, Stephen B. (2002). Model-Model Teologi Kontekstual. Terjemahan. Yosef Maria Florisan. Ledalero. Maumere.

Capra, Fritjof (1999). Menyatu dengan Semesta: Menyikap Batas antara Sains dan Spiritualitas. Terjemahan Saut Pasaribu. Fajar Pustaka Baru. Yogyakarta.

Erler, Brigitte (1989), Bantuan Mematikan. LP3ES. Jakarta.

Freidman, J. (1992). Empowerment: The Politics of Alternative Development. Blackwell Publishers. Cambridge, USA.

Fukuyama (1999). The End of History and The Last Man: Kemenangan Kapitalisme dan Demokrasi Liberal. Penerbit Qalam. Yogyakarta.

Hardiman, F. Budi (2007). Filsafat Modern Dari Machiavelli sampai Nietzsche. PT Gramedia Pustaka Utama. Jakarta.

Indrati S. \& Maria Farida (2008). Ilmu Peraturan Perundang-undangan: Jenis, Fungsi, dan Materi Muatan. Penerbit Kanisius. Yogyakarta.

James, Spillane, J. (1994). Pariwisata Indonesia, Sejarah dan Prospeknya. Yogyakarta: Kanisius

Koentjaraningrat (1980). Sejarah Teori Antropologi. Penerbit Universitas Indonesia. Jakarta. Koentjaraningrat (1982). Beberapa Pokok Antropologi Sosial. Penerbit Universitas Indonesia. Jakarta.

Koentjaraningrat (2004). Manusia dan Kebudayaan di Indonesia. Penerbit Universitas Indonesia. Jakarta.

Koentjaraningrat (2009). Pengantar Ilmu Antropologi. Edisi Revisi. Rineka Cipta. Jakarta.

Mertokusumo, Sudikno (2008). Mengenal Hukum (Sebuah Pengantar). Liberty.

Yogyakarta. Pendit, Nyoman S. (1999). Ilmu Pariwisata Sebuah Pengantar Perdana.

Pradnya Paramita. Jakarta.

Oka A. Yoeti (1983). Pengantar Ilmu Pariwisata. Angkasa, Bandung.

Pitana, I Gede \& Gayatri, Putu G. (2005). Sosiologi Pariwisata. Edisi ke 4. Andi Publisher. Surabaya.

Sediawati, Edy (2006) Budaya Indonesia Kajian Arkeologi, Seni, dan Sejarah. Raja Grafindo Persada. Jakarta.

Soemitro, R.A.A. \& Suprayitno (2018). "Pemikiran Awal tentang Prinsip Dasar Manajemen Aset Fasilitas. Jurnal Manajemen Aset Infrastruktur \& Fasilitas, Vol. 2, Sup. 1, Juni 2018, Hal. : 1-13.

Spillane J.J. (1987). Pariwisata Indonesia Sejarah dan Prospeknya. Penerbit Kanisius. Yogyakarta.

Sundjaya (2008). Dinamika Kebudayaan. Nobel Edomedia. Jakarta.

Sutopo. H.B. (2006). Metode Penelitian Kualitatif. Universitas Sebelas Maret.

Surakarta. Tinarbuko, Sumbo (2008). Semiotika Komunikasi Visual. Jalasutra.

Yogyakarta.

Usman, Soenyoto (1998). Pembangunan dan Pemberdayaan Masyarakat. Pustaka Pelajar. Yogyakarta. 
(e)ISSN 2615-1847 (p)ISSN 2615-1839

Jurnal Manajemen Aset Infrastruktur \& Fasilitas - Vol. 3, No. 1, Maret 2019

Widjaja, H.A.W. (2003). Otonomi Desa Merupakan Otonomi yang Asli, Bulat dan Utuh. PT Raja Grafindo Persada. Jakarta.

Wiyasa, Thomas (2002). Upacara Perkawinan Adat Sunda. Pustaka Sinar Harapan. Jakarta. 
(e)ISSN 2615-1847 $\quad$ (p)ISSN 2615-1839

Jurnal Manajemen Aset Infrastruktur \& Fasilitas - Vol. 3, No. 1, Maret 2019 
(e)ISSN 2615-1847 (p)ISSN 2615-1839

Jurnal Manajemen Aset Infrastruktur \& Fasilitas - Vol. 3, No. 1, Maret 2019 